\title{
Short Communication: The most active fraction of red turi flowers (Sesbania grandiflora) on the cytotoxic activity of HepG2 cells
}

\author{
SULASMI $^{1, \boldsymbol{\nu}}$, OKID P. ASTIRIN ${ }^{2}$, TETRI WIDIYANI ${ }^{2}$ \\ ${ }^{1}$ Biosain Postgraduate Program, Universitas Sebelas Maret. J1. Ir. Sutami No. 36A, Surakarta 57126, Central Java, Indonesia. \\ Tel.: +62-271-632450, ^email: alifakhumaira@ gmail.com. \\ ${ }^{2}$ Faculty of Mathematics and Natural Sciences, Universitas Sebelas Maret. Jl. Ir. Sutami No. 36A, Surakarta 57126, Central Java, Indonesia
}

Manuscript received: 25 January 2020. Revision accepted: 7 May 2020.

\begin{abstract}
Sulasmi, Astirin OP, Widiyanti T. 2020. Short Communication: The most active fraction of red turi flowers (Sesbania grandiflora) on the cytotoxic activity of HepG2 cells. Nusantara Bioscience 12: 68-72. Red turi flowers (Sesbania grandiflora L.Pers) contain many chemical compounds with high bioactivity. One of the chemical compounds is flavonoid compound. Quercetin is a class of flavonoid compound. This compound is obtained by extraction with methanol as a solvent then it is partitioned by water and ethyl acetate as a solvent. The fraction obtained is given phytochemical tests, which is further test using Thin Layer Chromatography (TLC) to detect the quercetin compounds. The level of flavonoid is determined using UV Vis spectrophotometer. Water and ethyl acetate fractions are tested cytotoxically using the MTT method (3-(4,5-dimethyltiazol-2-il)-2,5-diphenyltetrazolium bromide) with ELISA Microplate Reader. This study aims to determine the most active fraction of red turi flowers on the cytotoxic activity of HepG2 cells, which are model cells for liver cancer. The results of water fraction do not contain quercetin compounds, with $\mathrm{IC}_{50}$ value of $961.11 \mu \mathrm{g} / \mathrm{mL}$. The ethyl acetate fraction contains quercetin compounds with total flavonoid equivalent quercetin of $1.76 \% \mathrm{~b} / \mathrm{b}$ and $\mathrm{IC}_{50}$ value of $149.15 \mu \mathrm{g} / \mathrm{mL}$. Ethyl acetate fraction is more active than the water fraction with moderate cytotoxicity.
\end{abstract}

Keywords: Cytotoxic activity, ethyl acetate fraction, HepG2 cells, red turi flowers, Sesbania grandiflora, water fraction

\section{INTRODUCTION}

Cancer is one of the main causes of death around the world. The number of death cases caused by cancer in 2012 is 8.2 million deaths (Henjani et al. 2018). Heart cancer is one of the main health problems in developing countries, with the number of cases $>20$ people per 100.000 people in East Asia (North Korea, South Korea, China, and Vietnam) and Sub-Saharan Africa (Zhu et al. 2016). Hepatocellular carcinoma (HCC) is the most dominant primary liver cancer with various risk factors, such as hepatitis B virus infection, hepatitis $\mathrm{C}$ virus infection, Non-Alcoholic Steatohepatitis (NASH), history of alcoholic liver disease, aflatoxin exposure, and diabetes. About $70 \%$ to $90 \%$ cases of liver cancer occur in patients with chronic liver disease. Treatment, that is currently available, includes tumor resection, liver transplantation, loco-regional therapy (radiofrequency ablation, percutaneous ethanol injection, trans-catheter chemoembolization), systemic therapy (sorafenib, doxorubicin, and bevacizumab) and the use of markers (Maldonado et al. 2015).

Turi (Sesbania grandiflora L.Pers) is a tropical plant that grows in Asia (Bhoumik et al. 2016). One part of turi plants with high bioactivity potential that can be used as vegetables is the flower (Asmara 2017). Turi flowers contain $14.5 \mathrm{~g}$ of protein; $3.6 \mathrm{~g}$ fat; $77.3 \mathrm{~g}$ carbohydrates; $10.9 \mathrm{~g}$ of fiber; $145 \mathrm{mg}$ of calcium; $5.4 \mathrm{mg}$ of iron; $291 \mathrm{mg}$ of sodium; $1,400 \mathrm{mg}$ of potassium, and $70 \%$ of alcohol extract of turi flowers contains $64.0 \mathrm{mg}$ of total phenol, which is equivalent to catechol and $28.80 \mathrm{mg}$ of flavonoids, which is equivalent to quercetin (Lim 2014). Other chemical compounds contained in the turi flowers include flavonoids, alkaloids, tannins, and polyphenols, saponins, oleanolic acid, kaempferol-3-routineoside (Mahadik 2017).

Flavonoids are polar polyphenol compounds, in plants are usually bound as glycosides and aglycones (Haeria et al. 2016). Flavonoid glycosides are polar compounds generally soluble in polar solvents such as ethanol, methanol, butanol, and water. Conversely, less polar (semipolar) aglycones, such as isoflavones, flavanones, flavones and methylated flavonols, tend to be more easily dissolved in semi-polar solvents, such as ether, chloroform, ethyl acetate, and n-butanol (Markham 1988). One form of flavonoids mostly contained in vegetables and fruit is quercetin. Quercetin has anti-inflammatory, antihypertensive activity, vasodilator function, anti-obesity, reducing function of cholesterol levels, anti-atherosclerosis, and food additives due to its high antioxidant activity (Mahyuni 2016). The benefits of quercetin related to its cytotoxic activity is suppressing the proliferation and survival of HepG2 cells as well as inducing apoptosis by increasing the expression of p53 and BAX by suppressing the regulation of ROS, PKC, P13K, COX-2 (Maurya et al. 2015). Quercetin also induces p53 activation, which results in increased regulation of BAX and downregulation of BCL-2 in tumors, activating Caspase 3 and Caspase 9, which causes cell apoptosis (Khan 2016). 
Cytotoxicity test is a preliminary test with in vitro bioassay method, which is used to find out the toxicity of a substance in various tissues. This test is a major step to find a new anticancer drug derived from natural ingredients. Cytotoxicity test usually uses MTT method. This method measures viability, cell membrane integrity, cell proliferation, and metabolic activity (Tolosa et al. 2015). The measurement results are expressed with $\mathrm{IC}_{50}$ values. $\mathrm{IC}_{50}$ value is the magnitude of the concentration of a compound to cause life inhibition in $50 \%$ of cells or test animals (Mahardika et al. 2016). Based on this description, a study is conducted to find out the most active fraction of red turi flowers (Sesbania grandiflora L.Pers) on the cytotoxic activity of HepG2 cells.

\section{MATERIALS AND METHODS}

\section{Time and location}

This research was conducted in Laboratory of Parasitology, Faculty of Medicine, Gadjah Mada University (UGM), Yogyakarta, Indonesia. The secondary metabolite examination was carried out at UGM Integrated Research and Testing Laboratory and National Pharmacy Laboratory of Institute of Health Sciencef from January to June 2018.

\section{Materials}

Fresh red turi flowers of Sesbania grandiflora (L.) Pers) were obtained in Sukoharjo. The test cells, which are model of liver cancer cells in this study, are HepG2 cells (ATCC @ HB-8065), obtained from the Laboratory of Parasitology at Faculty of Medicine, Gadjah Mada University of Yogyakarta.

Chemicals needed in this research are methanol, ethyl acetate, water, secondary metabolite test reagents, Quercetin comparator (Sigma aldrich), cytotoxicity test reagents (Dulbecco's Modified Eagle Medium; DMEM) given 5\% of Foetal Bovine Serum (FBS) and $100 \mathrm{IU} / \mathrm{ml}$ of penicillin, SDS stopper reagent $10 \%$ in $0.01 \mathrm{~N} \mathrm{HCl}$, MTT reagent (3-(4,5-dimethylthiazol-2-yl)-2,5diphenyltetrazolium bromide), $0.25 \%$ trypsin-EDTA, and Dimethyl sulfoxide (DMSO) reagent.

\section{Procedure}

\section{Preparation of sample and extract}

Samples of red turi flowers were collected then washed using clean water and dried inside the room (not directly under the sun). Flowers were mashed and sieved with 65 mesh sieves. As many as 500 grams of red turi flower powder was extracted with $7500 \mathrm{~mL}$ of methanol for 3 x 24 hours. Filtrate was filtered using whatmann filter paper then evaporated using a rotary evaporator at $40^{\circ} \mathrm{C}$, obtaining concentrated extract (Lisi et al. 2017). The extract was processed with stratified partitioning by using water and ethyl acetate solvents then concentrated using a rotary evaporator to obtain water and ethyl acetate fractions (Iryani et al. 2017). Filtrate of water and ethyl acetate fractions was tested to know the content of phytochemical screening, alkaloids, flavonoids, tannins, terpenoids, and saponins according to the procedure in Nirwana et al (2015).

\section{Identification of quercetin compounds}

Quercetin compounds of filtrate that has been tested for phytochemical screening was then identified using Thin Layer Chromatography (TLC) and further tests of total flavonoid levels. Each sample was weighed and extracted by using $1 \mathrm{ml}$ of ethanol then put into vortex mixer for 2 minutes and centrifuged for 3 minutes. As much as $10 \mu \mathrm{l}$ of liquid phase was taken, spotted into plate silica gel $60 \mathrm{~F}_{254}$ (Al-sheet), as well as the quercetin comparator. Plate was put into the saturated chamber according to the mobile phase of butanol: acetic acid: water (4: 1: 5) for the ethyl acetate fraction and the mobile phase of chloroform: methanol: formic acid (9: 1: 0.4$)$ for water fraction. It was extracted to the limit, the plate was dried then observed under UV light 254, UV $366 \mathrm{~nm}$, with sulfuric acid anisaldehyde spray reagents and ammonia vapor spotting viewers (Nuari et al.2017; Irianti et al, 2016). The total level of flavonoids in the fraction with positive quercetin results was determined by using UV-Vis spectrophotometer (UV-1800 Shimadzu), with the procedure of making standard flavonoid curves and establishing test samples. Weigh $100 \mathrm{mg}$ of the sample carefully, put it in a test tube. Add $0.3 \mathrm{ml}$ of $\mathrm{NaNO} 25 \%$. After 5 minutes, add $0.6 \mathrm{ml}$ of $\mathrm{AlCl} 310 \%$. Wait for 5 minutes, add $2 \mathrm{ml}$ of $\mathrm{NaOH} 1 \mathrm{M}$. Add aquadest to $10 \mathrm{ml}$ with a measuring flask and dilute 5 times. Move it into the cuvette, keep it absorbing at a wavelength of $510 \mathrm{~nm}$. The results of total flavonoid levels obtained were equivalent to quercetin levels in the ethyl acetate fraction (Chang et al, 2002; Puspitasari et al, 2015).

\section{Cytotoxicity test}

As many as $80 \%$ confluent of HepG2 cell culture was distributed into 96-well plate microplate with a density of $10^{4}$ cells $/ 100 \mu \mathrm{L}$ media and incubated for 24 hours in $5 \%$ $\mathrm{CO} 2$ incubator at $37^{\circ} \mathrm{C}$. A total of $100 \mu \mathrm{L}$ of water and ethyl acetate fraction samples with various concentrations $(1000 ; 500 ; 250 ; 125 ; 62.50 ; 31.25 ; 15.625 ; 7.8125 \mu \mathrm{g} /$ $\mathrm{mL})$ were added to 96 -well plates then incubated for 24 hours in $5 \% \mathrm{CO} 2$ incubator at $37^{\circ} \mathrm{C}$. After 24 hours, 100 $\mu \mathrm{L}$ of MTT reagent was added into each well and reincubated for 4-6 hours in a 5\% CO2 incubator at $37^{\circ} \mathrm{C}$. MTT reaction was stopped by adding $100 \mu \mathrm{L}$ of stopper reagent $(10 \%$ SDS in $0.01 \mathrm{~N} \mathrm{HCl})$. After then, the microplate was re-incubated for 12 hours in a room temperature in a dark room. After incubation, the results were measured at $\lambda 595 \mathrm{~nm}$ (ELISA microplate reader). The percentage of HepG2 cell viability was calculated using formula:

$$
X=\frac{C-B}{A-B} \times 100 \%
$$

Where; $\mathrm{X}=\%$ viability, $\mathrm{A}=$ absorbance of cell control, $\mathrm{B}=$ absorbance of media control, and $\mathrm{C}=$ absorbance of sample (CCRC 2012). 


\section{Data analysis}

The percentage of cell viability is written as $\mathrm{IC}_{50} . \mathrm{IC}_{50}$ value is determined by linear regression analysis of $\log$ concentration or percent probit of SPPS for window 16.0 program. Meanwhile, the results are reported as cytotoxicity test results. A low $\mathrm{IC}_{50}$ value indicates high sample activity.

\section{RESULTS AND DISCUSSION}

\section{Phytochemical Screening and Identification of Quercetin Compounds}

The results of phytochemical screening of methanol extract of red turi flowers from each fraction are presented in Table 1. Flavonoid compound, especially quercetin compounds are seen in Figure 1. The Rf value formed by water and ethyl acetate fraction sample is compared to the standard of quercetin comparator.

The results of qualitative test of quercetin using Thin Layer Chromatography (TLC) of both fractions show that only ethyl acetate fraction contains quercetin compounds, with $\mathrm{Rf}$ value of 0.88 . Ethyl acetate fraction is then examined quantitatively using UV-Vis spectrophotometer. It obtains the total of flavonoid equivalent to quercetin of $1.76 \% \mathrm{~b} / \mathrm{b}$.

\section{Cytotoxicity of water fraction and ethyl acetate fraction}

Percentage of HepG2 cell viability of water and ethyl acetate fractions of methanol extract of red turi flowers are presented in Tables 2 and 3. $\mathrm{IC}_{50}$ value of water and ethyl acetate fractions of methanol extract of red turi flowers are presented in Table 4. Ethyl acetate fraction shows a higher cytotoxic effect on HepG2 cells than the water fraction. $\mathrm{IC}_{50}$ value is determined by putting the value $(\mathrm{Y}=50)$ into the linear regression equation. Based on the linear regression equation, IC50 value of each solvent can be seen in Figure 2 and 3.

Table 2. Viability of HepG2 cells to water fraction

\begin{tabular}{ll}
\hline Cocentration $(\boldsymbol{\mu g} / \mathbf{m l})$ & \% viability \\
\hline 250 & 100.4946628 \\
125 & 110.3879198 \\
62.5 & 116.6362926 \\
31.25 & 119.6563395 \\
15.625 & 113.9807342 \\
\hline
\end{tabular}

Table 3. Viability of HepG2 cells to ethyl acetate fraction

\begin{tabular}{ll}
\hline Cocentration $(\boldsymbol{\mu g} / \mathbf{m l})$ & \% viability \\
\hline 250 & 1.249674564 \\
125 & 74.14735746 \\
62.5 & 90.9658943 \\
31.25 & 93.46524343 \\
15.625 & 97.89117417 \\
\hline
\end{tabular}

Table 4. $\mathrm{IC}_{50}$ value of water fraction and ethyl acetate fraction on HepG2 cells

\begin{tabular}{ll}
\hline Fraction & IC $_{\mathbf{5 0}}$ \\
\hline Water & $961.11 \mu \mathrm{g} / \mathrm{mL}$ \\
Ethyl acetate & $149.15 \mu \mathrm{g} / \mathrm{mL}$ \\
\hline
\end{tabular}

Table 1. Phytochemical screening of water fraction and ethyl acetate fraction methanol extract of red turi flowers

\begin{tabular}{|c|c|c|c|}
\hline \multirow{2}{*}{$\begin{array}{l}\text { Test } \\
\text { parameters }\end{array}$} & \multicolumn{2}{|c|}{ Results } & \multirow[b]{2}{*}{ Information } \\
\hline & Water & $\begin{array}{c}\text { Ethyl } \\
\text { acetate }\end{array}$ & \\
\hline \multirow{2}{*}{ Alkaloid } & + & + & White precipitate (Mayer) \\
\hline & + & + & Yellow precipitate (Dragendorf) \\
\hline Flavonoid & + & + & Reddish orange \\
\hline Tannin & + & + & Greenish brown sediment \\
\hline Terpenoid & + & + & Brown ring \\
\hline Saponin & + & + & Foaming \\
\hline
\end{tabular}

Notes: +: Yes; -: No
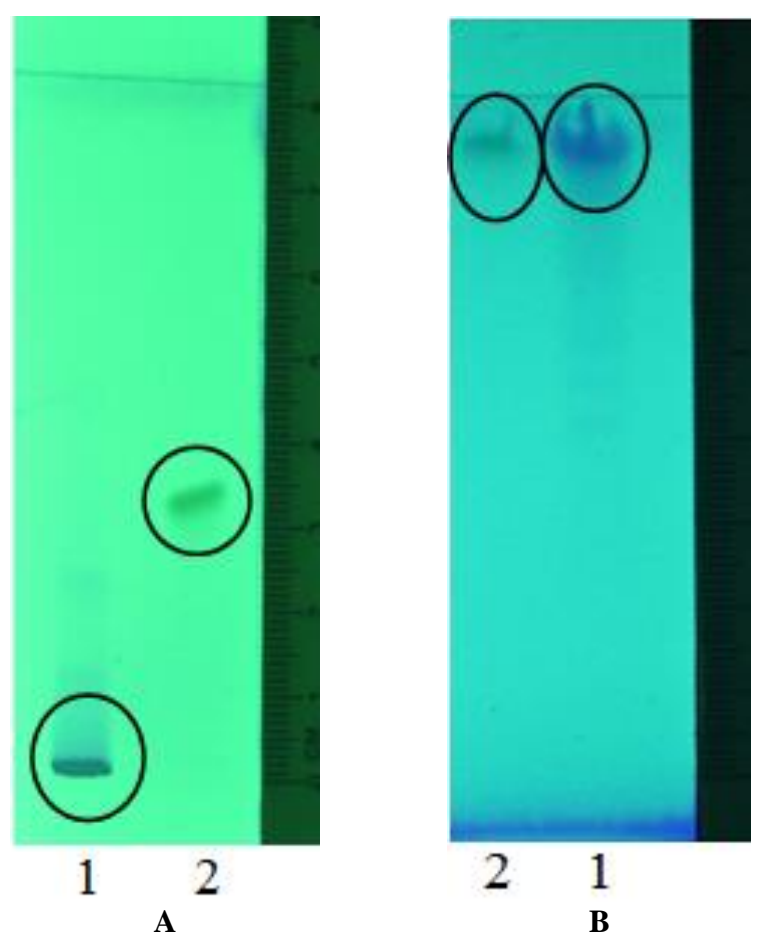

Figure 1.Chromatogram (A) water fraction and (B) Ethyl acetate fraction from methanol extract of red turi flowers compared to quercetin comparator routine. Note: A. Mobile Phase : Chloroform-methanol- formic acid; B. Mobile Phase : ButhanolAcetic Acid-Water. $\lambda$ : $254 \mathrm{~mm}$, 1: sample, 2: quercetin comparator routine 


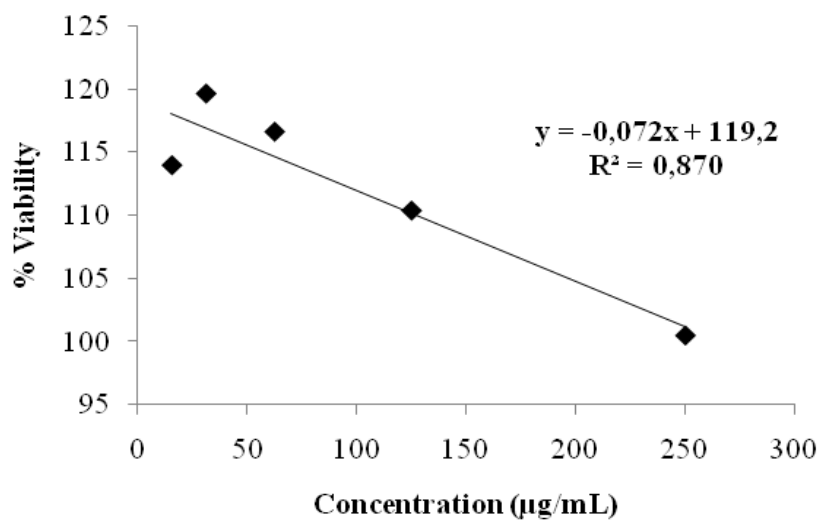

Figure 2. Graph of the corelation between life percentage of HepG2 cells and log concetration of water fraction of methanol extract of red turi flowers

\section{Discussion}

The extraction process in this study uses the maceration method with methanol organic solvents. Methanol is a universal polar solvent that can attract polar to semi-polar secondary metabolites such as flavonoids, alkaloids, steroids, and saponins (Jannah 2017). The active compound in a plant can be taken by extraction by using various solvents. Factors that influence the choice of solvent type are the ability to extract, selectivity, toxicity, ease of evaporation, and the price of solvent (Harborne 1987). The second stage of isolation process of secondary metabolites is partitioning through fractionation method by using organic solvents that differ in their polarity level, affecting the type and content of the extracted compound. Ethyl acetate solvents can be used to extract semi-polar compounds such as flavonoids in the form of O-glycosides and tannins (Tanaya et al. 2015). Meanwhile, polar solvents like water can dissolve polar compounds and nonpolar compounds because it has a large dipole moment (Suhendi et al. 2017).

The potential of natural substances on the cytotoxic activity of a cell can be determined by MTT test. This test uses colorimetric reading method, reduction of yellow salt of tetrazolium MTT (3-(4,5-dimethyltiazol-2-il)-2,5diphenyltetrazolium bromide) by the reductase system. Succinate-tetrazolium will form formazan crystals, which is purple and water insoluble. The addition of DMSO stopper reagents will dissolve formazon crystals. After then, the absorbance is measured using ELISA microplate reader at $\lambda 540-570 \mathrm{~nm}$. The intensity of the purple color is proportional to the number of living HepG2 cells. The greater the intensity of the purple color, the more the number of living HepG2 cells (Tolosa et al. 2015). IC 50 values are calculated using SPSS 16.0 probit analysis program for windows (Mahardika et al. 2016).

Several studies related to the bioactivity of compounds contained in turi flowers have been conducted. Roy et al (2013) state that the methanol extract of S.grandiflora (F2) flowers effectively inhibites human leukemia cell proliferation (U937) with $\mathrm{IC}_{50}$ value of $18.6 \mu \mathrm{g} / \mathrm{ml}$, through the autophagy and apoptosis mechanisms. The study of

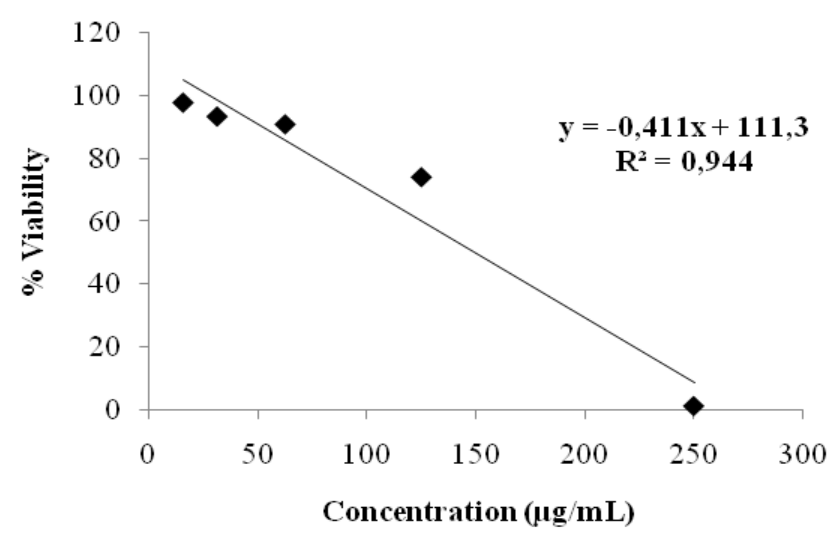

Figure 3. Graph of the correlation of life percentage of HepG2 cells and $\log$ concentration of ethyl acetate fraction of methanol extract of red turi flowers

Loganayaki et al (2012) also shows that the methanol extract of turi flowers has potential cytotoxic activity on human cervical cancer cell lines with $\mathrm{IC}_{50}$ value of 0.13 $\mathrm{mg} / \mathrm{mL}$, and it does not show cell death in normal embryonic fibroblasts of mice. Kumar et al (2015) state that $70 \%$ alcohol extract of turi flowers has antidiabetic activity in white rats.

The use of quercetin will increase the process of hepatoma cell death (HepG2) through two different mechanisms. First through the mitochondrial pathway, quercetin will induce p53 which will increase BAX regulation and suppress $\mathrm{BCL}-2$ regulation. This will activate Caspase 3 and caspase 9, but not caspase- 8 which will eventually cause cell apoptosis (Khan et al. 2016). Secondly by blocking the inhibition of the main cell survival signals, Akt and Extracellular signal-regulated kinase (ERK) (Murakami 2008). Quercetin also regulates the internal and external pathways of Protein Kinase $\mathrm{C}$ (PKC) signaling mediated by ROS. Quercetin will suppress the proliferation and survival of HepG2 cells and induce apoptosis by increasing the expression of p53 and BAX by suppressing the regulation of ROS, PKC, P13K, and COX2 (Maurya 2015).

Based on Table 2, $\mathrm{IC}_{50}$ value of ethyl acetate fraction is $149.15 \mu \mathrm{g} / \mathrm{mL}$, which is lower than $\mathrm{IC}_{50}$ value of water fraction, namely $961.11 \mu \mathrm{g} / \mathrm{mL}$ although both are still included in the moderate cytotoxicity level. Moderate cytotoxicity can be used for chemoprevention to prevent and to inhibit the growth of cancer cells (Prayong 2008). The difference in $\mathrm{IC}_{50}$ values in those two fractions is probably due to the distribution of types and amounts of secondary metabolite compounds that contain antioxidants based on the polarity of the solvent used (Septiani. 2018).

\section{ACKNOWLEDGEMENTS}

We would like to thank Dr. Ari Susilowati, Prof. Supargiyono (late), and Rumbiwati for supporting this research. 


\section{REFERENCES}

Asmara AP. 2017. Uji fitokimia senyawa metabolit sekunder dalam ekstrak metanol bunga turi merah (Sesbania grandiflora L.Pers). AlKimia (5) 1. [Indonesian]

Bhoumik D, Abera HB, Arunabha M. 2016. Evaluation of gastric antiulcer potency of ethanolic extract of Sesbania grandiflora Linn leaves in experimental anilmals. American Journal of Phytomedicine and Clinical Therapeutics 4 (6): 174-182.

CCRC [Cancer Chemoprevention Research Center]. 2012. Prosedur Tetap Uji Sitotoksik Metode MTT. Fakultas Farmasi Universitas Gadjah Mada. Yogyakarta. [Indonesian]

Chang CM, Yang M, Wen HCJ. 2002. Estimation of total flavonoid content in propolis by two complentary colorimetric methods. J Food Drugs Analysis.

Haeria, Hermawati, Andi Tenri UDP. 2016. Penetuan kadar flavonoid total dan aktivitas antioksidan ekstrak etanol daun bidara (Ziziphus spina-christi L.). J Pharm Med Sci 1(2): 57-61 [Indonesia].

Harborne JB. 1987. Metode Fitokimia : Penuntun Cara Modern Menganalisa Tumbuhan, Terbitan Kedua. Institut Teknologi Bandung. Bandung

Henjani N, Fathurrahman, Zein H. 2018. Efektivitas ekstrak temu mangga (Curcuma mangga) sebagai senyawa sitotoksik dalam kemopreventif dan strategi kemoterapi. Dinamika Kesehatan 9 (2). [Indonesian]

Irianti T, Yosi BM, Damiana NK, Desi RP, Kuswandi, Ratih AK. 2016. Pengaruh hidrolisis asam-basa terhadap aktivitas penangkapan radikal 2-2' difenil-1-pikril hidrazil (DPPH) fraksi air dari ekstrak etanolik buah talok (Mutingia calabura L.). Trad Med Journal 21 (1): 38-47 [Indonesian].

Iryani, Iswendi, Indria TK. 2017. Uji aktivitas anti diabetes mellitus senyawa metabolit sekunder fraksi air dari beras ketan hitam (Oryza satival.Var glutinosa) pada mencit putih. Eksakta 18(1). [Indonesian]

Jannah R, Husni MP, Nursanty R. 2017. Uji daya hambat ekstrak metanol daun sirsak (Annona muricata Linn.) terhadap bakteri Streptococcus mutans. J Natural 1 (17). [Indonesian]

Khan Fazlullah., Kamal N., Faheem M., Fatima I H., Mohammad A. Kalyan CNV., Seyed MN., Anupam B. 2016. Molecular Target Underlying The Anticancer Effects Of Quercetin. MDPI Journal. Nutrients, $8: 529$.

Kumar R, Suresh J, Santosh K, Dhanajaya DR, Shivakumar S. 2015 Evaluation of antidiabetic activity of alcoholic extract of Sesbania grandiflora flower in alloxan induced diabetic rats. Asian J Pharmacy and Pharmacology 1(1): 21-26.

Lim, T K. 2014. Edible Medicinal And Non Medicinal Plants. Vol 7. Flowers. Springer.

Lisi AKF, Runtuwene MRJ, Wewengkang DS, 2017. Uji fitokimia dan aktivitas antioksidan dari ekstrak metanol bunga soyogik (Saurauia bracteosa DC.) Pharmacon. Jurnal Ilmiah Farmasi UNSRAT, 6 (1): 53-61 [Indonesia]

Loganayaki N, Suganya N, Manian S. 2012. Evaluation of edible flowers of agathi (Sesbania grandiflora L. Fabaceae) for in vivo antiinflammatory and analgesic, and in vitro antioxidant potential. Food Science and Biotechnology 21 (2): 509-517.
Mahadik VJ, Komal MP, Kiran AW. 2017. Sesbania grandiflora (agastya): A review on its phytochemical and pharmacological profile. Int J Biol Pharm Res 9 (1): 1-6.

Mahardika AB, Subagus W, Mae SHW. 2016. Sitotoksisitas senyawa hasil isolasi daun Tithonia diversifolia (Hemsley) A. Gray terhadap sel T47D, MCF7 Dan EVSA-T. Majalah Farmaseutik 2 (2). [Indonesian]

Maldonado JT, Ignacio GJ, Jonathan AV, Adrian GA, Mario VC, Alejandra AA, Francisco EP, Aldo T, Juan FSA, Diego LCP. 2015. Diagnosis and treatment of hepatocelluler carcinoma : An update. World J Hepatol 7 (3): 362-376.

Markham KR. 1988. Cara Mengidentifikasi Flavonoid, Penerbit ITB. Bandung [Indonesian]

Maurya, AK and Manjula V. 2015. Anticarcinogenic Action of Quercetin by Downregulation of Phosphatidylinositol 3-Kinase (P13K) and Protein Kinase C (PKC) Via Induction of P53 in Hepatocellular carcinoma (HepG2) Cell Line. Mol Biol Rep 42: 1419-1429.

Mahyuni S. 2016. Determinasi kadar total polifenol terlarut, heperetin dan quercetin pada daun,kulit dan isi buah Citrus aurantifolia (Christm \& Panzer) Swingle. Fitofarmaka 6 (1) [Indonesia].

Murakami A, Hitoshi A, Juni T. 2008. Multitargeted cancer prevention by quercetin. Cancer Letters 269 (315-325).

Nirwana AP, Astirin OP, Widiyani T. 2015. Skrining fitokimia ekstrak etanol daun benalu kersen (Dendrophtoe pentandra L. Miq.). ELVIVO 3 (2) 9-15

Nuari S, Syaiful A, Akhmad K. 2017. Isolasi dan identifikasi senyawa flavonoid ekstrak etanol buah naga merah (Hylocereus polyrhizus (F.A.C.Weber) Briton \& Rose. Galenika Journal of Pharmacy 2(2): 118-125. [Indonesia]

Prayong P, Barusrux S, Weerapreeyakul N. 2008. Cytotoxic activity screening of some indigenous Thai plants. Fitoterapia 79 (7): 598 601.

Puspitasari AD, Suwijo P. 2015. Comparison of methods of producing bee propolis purified extract based on total flavonoid content using rutin as standard. Trad Med. J 20(2): 76-81.

Roy R, Kumar D, Cakhraborty B, Chowdhury C, Das P. 2013. Apoptotic and autophagic effect of Sesbania grandiflora flowers in human leukemic cells. Plos One 8 (8): e71672.

Septiani R, Marianne, Marline N. 2018. Uji aktivitas antioksidan ekstrak etanol fraksi N-Heksan serta fraksi etil asetat daun jamblang (Syzygium cumini L.Skeels) dengan metode DPPH. TM Conference Series $2: 361-366$.

Suhendi A, Landyyun RS, Dedi H. 2011. Isolasi dan identifikasi flavonoid dari daun dewandaru (Eugenia uniflora L.). J Pharmacon 12 (2): 73-8. [Indonesian]

Tanaya V, Rurini R, Suratmo. 2015. Fraksi semi polar dari daun mangga kasturi (Mangifera casturi Kosterm). Kimia Student Journal 1 (1): 778-784. [Indonesia].

Tolosa L, Maria TD, Maria Jose GL. 2015. General cytotoxicity assessment by means of the MTT Assay. Protocols in In Vitro Hepatocyte Research. Methods in Moleculer Biology Vol.2.

Zhu RX, Way KS, Ching LL, Man FY. 2016. Epidemiology of hepatocelluler carcinoma in the Asia-Pacific region. Gut and Liver (10): 3 . 